\title{
SIKAP DOSEN TERHADAP PEMBELAJARAN INTERPROFESIONAL EDUCATION (IPE) STUDI PADA DOSEN DI STIKES JENDERAL ACHMAD YANI YOGYAKARTA
}

\section{LECTURER ATTITUDE TOWARD INTERPROFESIONAL EDUCATION LEARNING (IPE) STUDY ON LECTURER IN STIKES JENDERAL ACHMAD YANI YOGYAKARTA}

\author{
Waode Syahrani Hajri ${ }^{1}$, Masta Hutasoit ${ }^{2 *}$, Retty Nirmala Santiasari ${ }^{3}$ \\ ${ }^{1}$ Akper PPNI Kendari, Akademi Keperawatan,PPNI, Jl. Jend. A.H Nasution, No.46G Kendari, Sulawesi \\ Tenggara,Indonesia \\ $\star^{2}$ Universitas Jenderal Achmad Yani Yogyakarta, Jl. Ringroad Barat, Gamping Sleman Yogyakarta, \\ Email: hutasoitmasta@gmail.com, Indonesia \\ ${ }^{3}$ Stikes William Booth Jl. Cimanuk No 20 Surabaya Jawa Timur, Indonesia
}

\begin{abstract}
Background: Application of IPE in academics prioritizes collaborative competencies to make students able to understand how to work interprofessionally, so as to foster readiness. Lecturer attitudes are considered as an important component in implementing successful IPE in academic environment.

Objective: The purpose of this study was to examine and analyse lecturers attitudes towards interprofessional education.

Method: This was descriptive comparative study with cross sectional design. Sampel were 31 lecturers from departments of nursing, midwifery, and medical record taken by purposive sampling. Modified questioner of Attitudes Toward Interprofessional Health Care Teams (ATHCT), Readiness for Interprofessional Learning Scale (RIPLS), and Attitudes Towards Interprofessional Learning in Academic Setting (ATILAS) were applied to examine lecturers attitudes.

Result: The results indicate lecturer's positive attitude toward IPE, with an average score of statement item $M=3.96$ on the attitude aspect to the interprofessional health care teams; $M=4.11$ on attitude aspect to interprofessional education; as well as on attitudes towards interprofessional learning in academic setting with $M=3,93$. Discipline, gender, and teaching experience have no significant relationship with overall attitudinal responses towards IPE.

Conclusions: These findings can be used as a consideration of the intitution in applying Interprofessional Education at the academic settings.
\end{abstract}

Keywords: Attitudes, Interprofessional Education, Lecturers

\section{PENDAHULUAN}

IPE atau Interprofessional Education merupakan proses pembelajaran yang terjadi ketika dua atau lebih profesi yang berbeda belajar berdampingan dengan tujuan meningkatkan pelayanan. ${ }^{1}$ IPE mempunyai tujuan untuk meningkatkan kompetensi kolaborasi tim keperawatan dan tindakan kolaborasi perawat dengan profesi lain. IPE adalah upaya untuk memberikan pengalaman mengenai cara berinteraksi menghormati profesi lain serta komunikasi yang baik dan benar. $^{2,3}$

Tim pelayanan kesehatan merupakan sekelompok profesional yang mempunyai aturan yang jelas, tujuan umum dan keahlian berbeda. Tim akan berjalan dengan baik bila setiap anggota tim memberikan kontribusi yang baik. Anggota tim kesehatan antara lain dokter, perawat, bidan, laboran, ahli gizi, radiolog, apoteker, fisioterapi dan tenaga kesehatan di bidang lainnya. Kolaborasi 
adalah hubungan timbal balik dimana pemberi pelayanan memegang tanggung jawab paling besar untuk perawatan dalam kerangka kerja di bidang masing-masing. Praktik kolaborasi mengarah pada tanggung jawab dalam manajemen pelayanan kepada pasien. ${ }^{4}$ World Health Organization (WHO) mengakui kolaborasi antara profesi dalam pendidikan dan praktik sebagai suatu strategi inovatif yang akan memainkan peran penting dalam mengurangi krisis tenaga kerja kesehatan global. Praktik kolaborasi memperkuat sistem kesehatan dan memperbaiki hasil kesehatan. ${ }^{5}$ Bentuk konsep kolaborasi antar profesional kesehatan dapat dimulai dari pendidikan yang terintegrasi.

Penerapan interprofessional education (IPE) dalam akademik berhubungan dengan perubahan pengetahuan dan kesadaran mahasiswa mengenai peran dan tanggung jawab, memahami kerjasama tim dan kolaborasi dengan profesi kesehatan lain. ${ }^{6}$ Dengan adanya pendidikan yang terintegrasi, mahasiswa mampu memahami bagaimana bekerja secara interprofesi, sehingga menumbuhkan kesiapan.

Peran dosen tidak terlepas dari keberhasilan proses pendidikan interprofessional di perguruan tinggi. Dosen merupakan salah satu komponen esensial dalam suatu sistem pendidikan di perguruan tinggi. Peran, tugas, dan tanggung jawab dosen sangat penting dalam mewujudkan peserta didik yang memiliki kompetensi untuk berkolaborasi. Apabila dosen sudah memiliki sikap yang positif terhadap pelaksanaan IPE, maka mahasiswa akan lebih mudah untuk diarahkan supaya mampu bekerjasama dengan tim yang lain.

Rumusan masalah pada penelitian ini adalah "Bagaimanakah sikap dosen mengenai Interprofessional Education". Tujuan umum dari penelitian ini adalah untuk mengetahui sikap dosen mengenai Interprofessional Education di salah satu STIKES di Yogyakarta".

\section{BAHAN DAN CARA PENELITIAN}

Jenis penelitian ini adalah penelitian kuantitatif non eksperimental. Rancangan penelitian yang digunakan adalah deskriptif dengan pendekatan cross sectional. Penelitian ini bertujuan untuk mengetahui sikap dosen mengenai IPE. Penelitian ini dilaksanakan pada tanggal 24-25 November 2015 di salah satu stikes yang terdapat di Yogyakarta. Populasi dalam penelitian ini adalah dosen pengajar di semua program studi kesehatan yang terdiri dari 22 orang dosen di Prodi SI Keperawatan, 23 orang dosen di Prodi DIII Kebidanan dan 2 orang dosen Prodi Rekam Medis. Total populasi 47 orang dosen. Pengambilan data untuk metode kuantitatif menggunakan kuesioner dilakukan menggunakan teknik purposive sampling yang diambil dari masing - masing program studi. Kriteria inklusi pada penelitian ini adalah dosen tetap program studi kesehatan dan dosen yang menyatakan 
bersedia menjadi responden. Adapun kriteria eksklusi pada penelitian ini adalah dosen yang sedang menjalan itugas belajar, dosen yang sedang cuti, dan dosen yang tidak hadir saat penelitian baik karena tugas luar atau ijin. Besar sample dihitung berdasarkan rumus Slovin, dan jumlah sampel minimal yang dihitung sebesar 30 responden.

Kuesioner dalam penelitian ini menggunakan kuesioner oleh Curran, Sharpe, and Forristal. $^{7}$ Kuesioner ini terdiri dari pertanyaan tentang karakteristik responden, 14 item pertanyaan dengan menggunakan skala Likert untuk mengukur sikap dosen terhadap tim kesehatan interprofessional yang diadaptasi dari kuesioner Attitudes Toward Interprofessional Health Care Teams (ATHCT) oleh Heinemann, 15-item pertanyaan skala Likert untuk menilai sikap dosen terhadap pendidikan interprofessional yang merupakan modifikasi kuesioner Readiness for Interprofessional Learning Scale (RIPLS) diadaptasi dari Parsell dan Bligh, dan 13-item pertanyaan skala Likert untuk menilai sikap dosen terhadap pembelajaran interprofesional dalam tatanan akademik diadaptasi dari kuesioner Attitudes Towards Interprofessional Learning in Academic Setting dari Gardner. Data penelitian ini dianalisis secara univariat. Hal ini dilakukan dengan mendeskripsikan setiap variabel penelitian untuk mengetahui gambaran data yang dikumpulkan.

\section{HASIL DAN PEMBAHASAN}

\section{Karakteristik Responden}

Tabel 1. Karakteristik Responden $(\mathbf{n}=\mathbf{3 0})$

\begin{tabular}{lcc}
\hline \multicolumn{1}{c}{ Karakteristik } & $\begin{array}{c}\text { Jumlah } \\
(\mathrm{n})\end{array}$ & $\begin{array}{c}\text { Presentasi } \\
(\%)\end{array}$ \\
\hline Program Studi & & \\
S1 Keperawatan & 15 & 50 \\
D III Kebidanan & 14 & 47 \\
D III RekamMedis & 1 & 3 \\
\hline 2. Jenis Kelamin & & \\
Laki-laki & 6 & 20 \\
Perempuan & 24 & 80 \\
\hline 3. Lama Mengajar & & \\
<5 tahun & 18 & 60 \\
25 tahun & 12 & 40 \\
\hline 4. Pendidikan & & \\
Terakhir & 3 & 10 \\
DIV & 7 & 23,3 \\
S1/ Ners & 20 & 66,7 \\
S2 & & \\
\hline \multicolumn{1}{c}{ Total } & 30 & 100 \\
\hline
\end{tabular}

Tabel 1 menunjukan bahwa responden paling banyak berasal dari program studi keperawatan $(50 \%)$ dan kebidanan $(47 \%)$, jenis kelamin mayoritas perempuan (80\%), lama mengajar dominan $<5$ tahun (60\%), dan pendidikan terakhir paling banyak S2 sebesar $(66,7 \%)$.

\section{Sikap Terhadap Kolaborasi Tim Kesehatan Interprofesional}

Tabel 2. Ringkasan skor rata-rata pada skala sikap terhadap kolaborasi tim kesehatan interprofesional berdasarkan program studi $(n=30)$

\begin{tabular}{ccccc}
\hline Item & Keperawatan & Kebidanan & $\begin{array}{c}\text { Rekam } \\
\text { Medis }\end{array}$ & Total Mean \\
\hline 1 & $4,20 \pm .41$ & $4,29 \pm .73$ & $4,00 \pm .00$ & $4,23 \pm .57$ \\
2 & $3,40 \pm .74$ & $3,43 \pm 1.16$ & $4,00 \pm .00$ & $3,43 \pm .94$ \\
3 & $4,53 \pm .51$ & $4,50 \pm .52$ & $4,00 \pm .00$ & $4,50 \pm .51$ \\
4 & $4,33 \pm .45$ & $4,36 \pm .75$ & $4,00 \pm .00$ & $4,33 \pm .61$ \\
5 & $4,33 \pm .62$ & $4,43 \pm .51$ & $4,00 \pm .00$ & $4,37 \pm .57$ \\
6 & $2,27 \pm .88$ & $2,29 \pm 1.20$ & $2,00 \pm .00$ & $2,27 \pm 1.02$ \\
7 & $3,53 \pm .83$ & $4,00 \pm .88$ & $4,00 \pm .00$ & $3,77 \pm .86$ \\
8 & $4,40 \pm .63$ & $4,50 \pm .65$ & $4,00 \pm .00$ & $4,43 \pm .63$ \\
9 & $3,47 \pm 1.13$ & $4,07 \pm .83$ & $4,00 \pm .00$ & $3,77 \pm 1.01$ \\
\hline
\end{tabular}




\begin{tabular}{ccccc}
\hline 10 & $3,67 \pm .82$ & $3,64 \pm 1.01$ & $4,00 \pm .00$ & $3,67 \pm .88$ \\
11 & $3,80 \pm .68$ & $4,21 \pm .80$ & $4,00 \pm .00$ & $4,00 \pm .74$ \\
12 & $4,13 \pm .83$ & $4,50 \pm .52$ & $4,00 \pm .00$ & $4,30 \pm .70$ \\
13 & $4,07 \pm .70$ & $4,36 \pm .50$ & $4,00 \pm .00$ & $4,20 \pm .61$ \\
14 & $4,00 \pm .66$ & $4,50 \pm .52$ & $4,00 \pm .00$ & $4,23 \pm .63$ \\
\hline Tot & $3,87 \pm .59$ & $4,08 \pm .61$ & $3,86 \pm .00$ & $3,96 \pm .58$
\end{tabular}

Hasil penilaian sikap dosen terhadap

kolaborasi tim interprofessional menunjukkan nilai rata-rata sebesar 55,50 (SD = 4.93), dengan nilai minimum 46 dan nilai maksimum 66. Hasil pengelompokan kategori sikap terhadap kolaborasi tim interprofessional menunjukan bahwa keseluruhan responden memiliki kategori sikap baik.

Tabel 3 Rekapitulasi perbedaan skor rata-rata sikap terhadap kolaborasi tim

kesehatan interprofesional berdasarkan karakteristik $(\mathrm{n}=\mathbf{3 0})$

\begin{tabular}{|c|c|c|c|c|}
\hline & $\mathrm{N}$ & $\begin{array}{c}\text { Skor sikap } \\
\text { terhadap } \\
\text { kolaborasi tim } \\
\text { interprofesional } \\
(x \pm \text { SD) }\end{array}$ & $\begin{array}{c}\text { Mean } \\
\text { Differe } \\
\text { nce }\end{array}$ & $\begin{array}{c}\text { p- } \\
\text { value }\end{array}$ \\
\hline \multicolumn{5}{|l|}{$\begin{array}{l}\text { Program } \\
\text { studi: }\end{array}$} \\
\hline Keperawatan & 15 & $54,13 \pm 4,17$ & $-2,938$ & 0,116 \\
\hline Kebidanan & 14 & $57,01 \pm 5,51$ & - & \\
\hline Rekam medik & 1 & - & & \\
\hline \multicolumn{5}{|l|}{$\begin{array}{l}\text { Jenis Kelamin } \\
\text { : }\end{array}$} \\
\hline $\begin{array}{l}\text { Laki-laki } \\
\text { Perempuan }\end{array}$ & $\begin{array}{c}6 \\
24\end{array}$ & $\begin{array}{l}52,17 \pm 2,13 \\
56,33 \pm 5,09\end{array}$ & $-4,17$ & 0,063 \\
\hline \multicolumn{5}{|l|}{ Lama } \\
\hline $\begin{array}{l}<5 \text { tahun } \\
\geq 5 \text { tahun }\end{array}$ & $\begin{array}{l}18 \\
12\end{array}$ & $\begin{array}{l}56,56 \pm 5,23 \\
53,92 \pm 4,14\end{array}$ & 2,64 & 0,154 \\
\hline \multicolumn{5}{|l|}{$\begin{array}{l}\text { Pendidikan } \\
\text { terakhir ; }\end{array}$} \\
\hline DIV & 3 & $58,33 \pm 5,03$ & 2,19 & \\
\hline S1/ Ners & 7 & $56,14 \pm 3,63$ & 1,29 & 0,49 \\
\hline S2 & 20 & $54,85 \pm 5,32$ & & \\
\hline Total & 30 & & & \\
\hline
\end{tabular}

Hasil analisa statistik dengan uji t tidak berpasangan menunjukkan bahwa tidak terdapat perbedaan bermakna rata-rata skor sikap terhadap kolaborasi tim kesehatan interprofesional antara program studi keperawatan maupun kebidanan dengan nilai $\mathbf{p}=\mathbf{0 , 1 1 6}$. Pada kategori jenis kelamin, lama mengajar, latar belakang pendidikan, juga tidak ditemukan perbedaan skor rata-rata sikap secara signifikan. Dengan nilai $p$ masing-masing , $p=0.06, p=0.15, p=0.49$.

\section{Sikap terhadap pendidikan}

Interprofesional

Tabel 4. Ringkasan skor rata-rata sikap terhadap pendidikan interprofesional berdasarkan program studi $(n=30)$

\begin{tabular}{ccccc}
\hline Item & Keperawatan & Kebidanan & $\begin{array}{c}\text { Rekam } \\
\text { Medis }\end{array}$ & $\begin{array}{c}\text { Total } \\
\text { Mean }\end{array}$ \\
\hline 1 & $4,13 \pm .64$ & $4,50 \pm .52$ & $4,00 \pm .00$ & $4.30 \pm .60$ \\
2 & $3,53 \pm .99$ & $4,14 \pm .86$ & $4,00 \pm .00$ & $3.83 \pm .95$ \\
3 & $4,53 \pm .64$ & $4,64 \pm .50$ & $4,00 \pm .00$ & $4.57 \pm .57$ \\
4 & $4,20 \pm .56$ & $4,43 \pm .51$ & $4,00 \pm .00$ & $4.30 \pm .54$ \\
5 & $4,13 \pm .64$ & $4,29 \pm .61$ & $4,00 \pm .00$ & $4.20 \pm .61$ \\
6 & $4,13 \pm .64$ & $4,00 \pm .88$ & $4,00 \pm .00$ & $4.07 \pm .74$ \\
7 & $4,33 \pm .62$ & $4,07 \pm .92$ & $4,00 \pm .00$ & $4.20 \pm .76$ \\
8 & $4,27 \pm .88$ & $4,43 \pm .51$ & $4,00 \pm .00$ & $4.33 \pm .71$ \\
9 & $3,93 \pm .80$ & $4,43 \pm .51$ & $4,00 \pm .00$ & $4.17 \pm .70$ \\
10 & $4,33 \pm .49$ & $4,50 \pm .65$ & $4,00 \pm .00$ & $4.40 \pm .56$ \\
11 & $4,07 \pm .46$ & $3,43 \pm 1.34$ & $4,00 \pm .00$ & $3.77 \pm .101$ \\
12 & $4,53 \pm .52$ & $4,57 \pm .51$ & $4,00 \pm .00$ & $4.53 \pm .51$ \\
13 & $4,20 \pm .68$ & $4,36 \pm .63$ & $4,00 \pm .00$ & $4.27 \pm .64$ \\
14 & $4,27 \pm .70$ & $4,57 \pm .51$ & $4,00 \pm .00$ & $4.40 \pm .62$ \\
15 & $4,40 \pm .63$ & $4,36 \pm .50$ & $4,00 \pm .00$ & $4.37 \pm .56$ \\
\hline Tot & $4,20 \pm .25$ & $4,31 \pm .31$ & $4,00 \pm .00$ & $4,11 \pm .42$ \\
al & & & &
\end{tabular}
al

IPE menunjukkan nilai rata-rata sebesar $63,70(\mathrm{SD}=6.38)$, dengan nilai minimum 52 dan nilai maksimum 75. Hasil pengelompokan kategori sikap terhadap IPE menunjukan bahwa keseluruhan responden memiliki kategori sikap baik. Tabel 4 menunjukkan rekapitulasi skor rata-rata tiap item pertanyaan per program studi mengenai sikap terhadap IPE. Secara keseluruhan, responden yang berasal dari program studi kebidanan memiliki skor tertinggi $(M=4,31$, $\mathrm{SD}=.31)$. 
Hasil analisa statistik dengan uji t tidak berpasangan menunjukkan bahwa tidak terdapat perbedaan bermakna rata-rata skor sikap terhadap IPE antara program studi keperawatan maupun kebidanan dengan nilai $\mathbf{p}=\mathbf{0 , 4 8 5}$. Pada kategori jenis kelamin, lama mengajar, latar belakang pendidikan, juga tidak ditemukan perbedaan skor rata-rata sikap secara signifikant. Dengan nilai $p$ masing-masing, $p=0.225, p=0.26, p=0.112$. Hasil lengkap analisis statistik tersebut dijelaskan dalam tabel 5.

Tabel 5. Rekapitulasi perbedaan skor rata-rata sikap terhadap IPEberdasarkan program studi, jenis kelamin, lama mengajar dan pendidikan

\begin{tabular}{|c|c|c|c|c|}
\hline & $\mathrm{N}$ & $\begin{array}{c}\text { Skor sikap } \\
\text { terhadap IPE } \\
(x \pm S D)\end{array}$ & $\begin{array}{c}\text { Mean } \\
\text { Differen } \\
\text { ce }\end{array}$ & $\begin{array}{c}\text { p- } \\
\text { value }\end{array}$ \\
\hline $\begin{array}{l}\text { Program studi: } \\
\text { Keperawatan } \\
\text { Kebidanan } \\
\text { Rekam medik }\end{array}$ & $\begin{array}{c}15 \\
14 \\
1 \\
\end{array}$ & $\begin{array}{c}63,00 \pm 6,67 \\
64,71 \pm 6,34 \\
-\end{array}$ & $\begin{array}{c}-1,71 \\
-\end{array}$ & 0,485 \\
\hline Jenis Kelamin: & & & & \\
\hline $\begin{array}{l}\text { Laki-laki } \\
\text { Perempuan }\end{array}$ & $\begin{array}{c}6 \\
24 \\
\end{array}$ & $\begin{array}{l}60,83 \pm 6,62 \\
64,42 \pm 6,23\end{array}$ & $-3,58$ & 0,225 \\
\hline $\begin{array}{l}\text { Lama } \\
\text { Mengajar: } \\
<5 \text { tahun } \\
\geq 5 \text { tahun }\end{array}$ & $\begin{array}{l}18 \\
12\end{array}$ & $\begin{array}{l}64,78 \pm 6,49 \\
62,08 \pm 6,11\end{array}$ & 2,69 & 0,26 \\
\hline $\begin{array}{l}\text { Pendidikan } \\
\text { terakhir: } \\
\text { DIV } \\
\text { S1/ Ners } \\
\text { S2 }\end{array}$ & $\begin{array}{c}3 \\
7 \\
20 \\
\end{array}$ & $\begin{array}{l}68,00 \pm 7,55 \\
66,71 \pm 5,62 \\
62,00 \pm 6,07\end{array}$ & $\begin{array}{l}1,27 \\
4,71\end{array}$ & 0,112 \\
\hline Total & 30 & & & \\
\hline
\end{tabular}

\section{Sikap Terhadap Pembelajaran IPE dalam} Lingkup Akademik

Hasil penilaian sikap dosen terhadap metode pembelajaran IPE menunjukkan nilai rata-rata sebesar $51,03(S D=6.44)$, dengan nilai minimum 43 dan nilai maksimum 63.
Hasil pengelompokan kategori sikap terhadap metode pembelajaran IPE menunjukan bahwa keseluruhan responden memiliki kategori sikap baik.

\section{Tabel 6. Ringkasan skor rata-rata sikap terhadap metode pembelajaran IPE berdasarkan program studi}

\begin{tabular}{ccccc}
\hline Item & Keperawatan & Kebidanan & Rekam Medis & Total Mean \\
\hline 1 & $3,67 \pm .72$ & $3,79 \pm .80$ & $4,00 \pm .00$ & $3.73 \pm .74$ \\
2 & $4,20 \pm .68$ & $4,36 \pm .63$ & $4,00 \pm .00$ & $4.27 \pm .64$ \\
3 & $4,00 \pm .54$ & $3,79 \pm 1.12$ & $4,00 \pm .00$ & $3.90 \pm .85$ \\
4 & $3,33 \pm .72$ & $3,50 \pm .102$ & $4,00 \pm .00$ & $3.43 \pm .86$ \\
5 & $3,87 \pm .92$ & $3,71 \pm .99$ & $4,00 \pm .00$ & $3.80 \pm .93$ \\
6 & $4,33 \pm .49$ & $4,43 \pm .65$ & $4,00 \pm .00$ & $4.37 \pm .56$ \\
7 & $3,47 \pm .99$ & $3,79 \pm .98$ & $2,00 \pm .00$ & $3.57 \pm .101$ \\
8 & $3,93 \pm .80$ & $3,93 \pm .83$ & $4,00 \pm .00$ & $3.93 \pm .79$ \\
9 & $4,13 \pm .74$ & $4,36 \pm .63$ & $4,00 \pm .00$ & $4.23 \pm .68$ \\
10 & $4,33 \pm .49$ & $4,29 \pm .91$ & $4,00 \pm .00$ & $4.30 \pm .70$ \\
11 & $3,93 \pm .80$ & $4,00 \pm .96$ & $4,00 \pm .00$ & $3.97 \pm .85$ \\
12 & $3,73 \pm .96$ & $4,43 \pm .51$ & $3,00 \pm .00$ & $4.03 \pm .85$ \\
13 & $3,53 \pm .92$ & $3,43 \pm 1.09$ & $4,00 \pm .00$ & $3.50 \pm .97$ \\
\hline Total & $3,89 \pm .33$ & $3,99 \pm .35$ & $3,77 \pm .00$ & $3,93 \pm .31$ \\
\hline
\end{tabular}

Tabel 6 menunjukkan rekapitulasi skor rata-rata tiap item pertanyaan per program studi mengenai sikap terhadap metode pembelajaran IPE. Secara keseluruhan, responden yang berasal dari program studi kebidanan memiliki skor tertinggi $(\mathrm{M}=3,99, \mathrm{SD}=.35)$.

Hasil analisa statistik dengan uji t tidak berpasangan menunjukkan bahwa tidak terdapat perbedaan bermakna rata-rata skorsikap terhadap metode pembelajaran IPE antara program studi keperawatan maupun kebidanan dengan nilai $\mathbf{p}=0,59$. Pada kategori jenis kelamin, lama mengajar, latar belakang pendidikan, juga tidak ditemukan perbedaan skor rata-rata sikap secara signifikan. Dengan nilai $p$ masing-masing, $p=0.72, \quad p=0.38, \quad p=0.59$. Hasil lengkap 
analisis statistik tersebut dijelaskan dalam tabel 7.

Tabel 7 Rekapitulasi perbedaan skor rata-rata sikap terhadap metode pembelajaran ipe berdasarkan program studi, jenis kelamin, lama mengajar dan pendidikan terakhir $(n=30)$

\begin{tabular}{|c|c|c|c|c|}
\hline & $\mathrm{N}$ & $\begin{array}{c}\text { Skor sikap } \\
\text { terhadap } \\
\text { IPE } \\
(x \pm S D)\end{array}$ & $\begin{array}{c}\text { Mean } \\
\text { Differe } \\
\text { nce }\end{array}$ & $\begin{array}{c}p- \\
\text { value }\end{array}$ \\
\hline \multicolumn{5}{|l|}{ Program studi: } \\
\hline Keperawatan & 15 & $50,47 \pm 5,60$ & $-1,32$ & 0,59 \\
\hline Kebidanan & 14 & $51,79 \pm 7,57$ & - & \\
\hline Rekam medik & 1 & - & & \\
\hline \multicolumn{5}{|l|}{ Jenis Kelamin : } \\
\hline Laki-laki & 6 & $50,17 \pm 4,54$ & $-1,08$ & 0,72 \\
\hline Perempuan & 24 & $51,25 \pm 6,89$ & & \\
\hline \multicolumn{5}{|l|}{ Lama } \\
\hline Mengajar & 18 & $51,89 \pm 6,86$ & 2,14 & 0,38 \\
\hline $\begin{array}{l}<5 \text { tahun } \\
\geq 5 \text { tahun }\end{array}$ & 12 & $49,75 \pm 5,79$ & & \\
\hline \multicolumn{5}{|l|}{$\begin{array}{l}\text { Pendidikan } \\
\text { terakhir ; }\end{array}$} \\
\hline DIV & 3 & $54,00 \pm 8,54$ & 4,57 & \\
\hline S1/ Ners & 7 & $49,43 \pm 6,08$ & $-1,72$ & 0,59 \\
\hline S2 & 20 & $51,15 \pm 6,44$ & & \\
\hline Total & 30 & & & \\
\hline
\end{tabular}

\section{PEMBAHASAN}

\section{Sikap Dosen terhadap Kolaborasi Tim}

\section{Kesehatan Interprofesional}

Hasil pengukuran sikap dosen terhadap kolaborasi tim interprofesional menunjukan bahwa secara keseluruhan responden memiliki sikap baik (positif). Setelah dilakukan perbandingan nilai rata-rata sikap berdasarkan program studi, tidak didapatkan perbedaan bermakna terhadap nilai rata-rata sikap terhadap kolaborasi tim interprofesional. Walaupun dari hasil analasis menunjukan bahwa program studi kebidanan memiliki nilai mean yang paling tinggi $(\mathrm{M}=$
57.01, $S D=5.51$ ), namun perbedaan rerata antara kategori program studi tidak menunjukan nilai yang signifikan berbeda. Dimana keperawatan memiliki nilai mean sebesar $54.13(\mathrm{SD}=4.17)$.

Hasil penelitian ini tidak sejalan dengan penelitian yang dilakukan oleh Delnat yang menemukan adanya pengaruh disiplin ilmu terhadap sikap dosen tentang kolaborasi tim interprofesional. $^{8}$ Hasil penelitian lainnya menyebutkan bahwa atar belakang profesi merupakan salah satu aspek yang berhubungan dengan sikap terhadap IPE dan kolaborasi interprofesional. ${ }^{7}$ Dosen dengan profesi berbeda dilatih pada sistem pendidikan dan konteks pembelajaran yang berbeda sehingga menyebabkan adanya perbedaan nilai-nilai dan sikap dari tiap profesi. $^{7}$

Adanya nilai mean sikap responden terhadap kolaborasi tim interprofesional yang hampir sama pada tiap program studi dapat disebabkan karena semua responden baik program studi keperawatan, kebidanan, dan rekam medik memiliki intensitas interaksi dan komunikasi karena berada dalam lingkungan intustusi yang sama, mengajar di gedung yang sama, serta memiliki ruang dosen yang berdekatan. Hal lain yang bisa turut mempengaruhi adalah ketiga program studi tersebut sama-sama belum pernah terpapar oleh IPE. Sikap seseorang dapat dipengaruhi oleh pengalaman pribadi, intelegensia, lingkungan, maupun intitusi atau lembaga pendidikan. $^{9}$ 
Rata-rata skor item pertanyaan pada kuesioner sikap terhadap kolaborasi tim interprofesional menunjukan bahwa secara keseluruhan responden memiliki sikap positif $(\mathrm{M}=3.93, \mathrm{SD}=0.31)$. Skor tertinggi ditunjukan pada item pernyataan sikap memberi dan menerima pendapat/ bantuan diantara anggota tim interprofessional akan membantu dalam membuat keputusan yang lebihbaik $(4,50 \pm .51)$, serta pada item pernyataan pendekatan interprofesional meningkatkan kualitas pelayanan kesehatan $(4,43 \pm .63)$. Skor terendah yaitu pada komponen waktu yang dihabiskan dalam bekerja secara interprofesional. (2,27 \pm 1.02). Hal ini menunjukkan bahwa responden menganggap pentingnya kolaborasi interprofesional untuk mewujudkan peningkatan kualitas pelayanan kesehatan kepada pasien dengan menerapkan sikap saling mengahargai disiplin ilmu lainnya dan menerapkan komunikasi interprofesional, walaupun memerlukan waktu yang lebih banyak dalam pelaksanaannya. IPEC ${ }^{2}$ menyebutkan bahwa dinamika tim dalam melakukan perencanan dan pelayanan kesehatan dapat menghasilkan pelayanan yang efektif, efisien dan mewujudkan patient safety.

Analisis berdasarkan karakteristik responden menunjukan bahwa jenis kelamin, lama mengajar dan pendidikan terakhir tidak mempengaruhi sikap dosen terhadap kolaborasi tim interprofesional. Hal ini memberikan gambaran akan kesiapan secara keseluruhan dalam menerapkan IPE dan bahwa dosen telah menyadari akan pentingnya penerapan IPE terlepas dari latar belakang pendidikan dan lama mengajarnya, karena kolaborasi dan bekerja sama dalam tim interprofesional merupakan komponen yang menentukan pelaksanaan IPE. ${ }^{10}$ Salah satu yang hal yang menonjol dalam pelaksanaan IPE adalah praktek kolaborasi. ${ }^{11}$

\section{Sikap Dosen terhadap pendidikan Interprofesional}

Hasil pengukuran sikap dosen terhadap pendidikan interporofesional menunjukkan bahwa secara keseluruhan responden memiliki sikap baik (positif). Setelah dilakukan perbandingan nilai rata-rata sikap berdasarkan program studi, tidak terdapat perbedaan bermakna terhadap nilai rata-rata sikap terhadap pendidikan interprofesional. Walaupun dari hasil analisis menunjukkan bahwa responden yang berasal dari program studi kebidanan memiliki skor tertinggi ( $M=$ $51,79 \mathrm{SD}=7,57)$, namun perbedaan rerata antara kategori program studi tidak menunjukan nilai yang signifikan berbeda. Dimana keperawatan memiliki nilai mean sebesar 50,47 (SD=5,60).

Analisis perbedaan skor rata-rata sikap terhadap pendidikan interprofesional berdasarkan jenis kelamin, lama mengajar dan pendidikan terakhir menunjukan bahwa tidak adanya perbedaan bermakna, yang berarti bahwa jenis kelamin, lama mengajar dan pendidikan terakhir tidak mempengaruhi 
sikap dosen terhadap pendidikan interprofesional.

Hasil penelitian ini tidak sejalan dengan penelitian yang dilakukan oleh Delnat yang menemukan adanya pengaruh yang signifikan antara disiplin ilmu terhadap sikap dosen tentang pendidikan interprofesional. ${ }^{8}$ Hal yang sama juga dikemukakan oleh Curran bahwa disiplin ilmu dan jenis kelamin merupakan aspek yang berpengaruh signifikan terhadap pendidikan interprofesional, sedangkan pengalaman belajar dan umur tidak berhubungan dengan sikap dosen terhadap IPE. ${ }^{7}$ Curran menyebutkan bahwa jenis kelamin dan disiplin ilmu merupakan karakteristik yang berkaitan dengan sikap terhadap pendidikan interprofesional. $^{7}$ Salah satu hambatan pelaksanaan IPE adalah adanya perasaan tidak terbiasa dan kurang nyaman dengan proses pembelajaran yang melibatkan interdisipliner dari beberapa latar belakang pendidikan/ profesi berbeda. ${ }^{12}$ Adapun hasil penelitian dari Delnat menyebutkan bahwa dosen yang belum mempunyai pengalaman mengenai IPE disebabkan oleh hambatan dalam sistem dan sarana prasarana di Institusi. ${ }^{8}$ Selain itu, antara jenis kelamin wanita dan pria mempunyai persepsi yang berbeda terhadap pendidikaninterprofesional yang kemudianjuga akan memengaruhi sikap mereka terhadap pendidikaninterprofesional.

Analasis lebih lanjut pada rata-rata skor item pertanyaan kuesioner sikap terhadap pendidikan interprofesional menunjukan bahwa secara keseluruhan responden memiliki sikap positif $(M=4,11 S D=0.42)$. Skor tertinggi (4.57 \pm .57) ditunjukan pada item pernyataan "Pembelajaran interprofessional sebelum memasuki tahap klinik/profesi akan membantu mahasiswa profesi kesehatan mengembangkan kemampuan kolaborasinya menjadi tim kerja

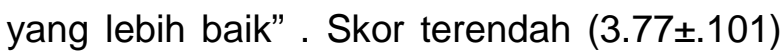
yaitu pada item pernyataan "pembelajaran interprofesional akan membantu mahasiswa untuk memahami keterbatasan profesi masing-masing".

\section{Sikap Dosen terhadap Pembelajaran Interprofesional}

Hasil pengukuran sikap dosen terhadap metode pembelajaran IPE menunjukan bahwa secara keseluruhan responden memiliki sikap positif. Setelah dilakukan perbandingan nilai rata-rata sikap berdasarkan program studi, tidak didapatkan perbedaan bermakna terhadap nilai rata-rata sikap terhadap metode pembelajaran IPE. Walaupun dari hasil analasis menunjukan bahwa program studi kebidanan memiliki nilai mean yang paling tinggi $(\mathrm{M}=51.79, \mathrm{SD}=$ 7.57), namun perbedaan rerata antara kategori program studi tidak menunjukan nilai yang signifikan berbeda. Dimana perbedaan skor mean diantara program studi hanya sebesar 1,32 .

Hasil penelitian ini sejalan dengan penelitian yang dilakukan oleh Delnat yang menunjukkan tidak adanya pengaruh disiplin 
ilmu terhadap sikap dosen tentang metode pembelajaran IPE. ${ }^{8}$ Hal ini dapat disebabkan karena ketiga program studi berada pada satu yayasan yang sama, sehingga kebijakan dan pengaturan metode pembelajaran yang diterapkan tidak akan mengalami perbedaan antara tiap program studi.

Penelitian yang dilakukan oleh Curran menunjukan bahwa jenis kelamin dan pengalaman/ lama mengajar mempengaruhi sikap dosen terhadap metode pembelajaran IPE. $^{7}$ Hal ini tidak didapatkan dalam penelitian yang penulis lakukan. Dimana didapatkan tidak adanya perbedaan rata-rata skor sikap responden terhadap metode pembelajaran IPE berdasarkan jenis kelamin, lamanya mengajar, maupun pendidikan. Pendidikan pada dasarnya merupakan faktor yang dapat mempengaruhi sikap seseorang. ${ }^{9}$

Berdasarkan rekapitulasi skor mean tiap item pertanyaan pada kuesioner sikap terhadap metode pembelajaran IPE dapat dilihat bahwa item pertanyaan nomor dua (2), enam (6) dan (10) memiliki skor mean terbesar. Yaitu masing-masing $M=4.27 \pm .64$, $M=4.37 \pm .56$, dan $M=4,30 \pm 70$. Maka dapat disimpulkan bahwa responden mendukung penerapan pembelajaran interprofesional bagi program studi kesehatan, responden juga menganggap perlunya dukungan intitusi terhadap dosen untuk berpartisipasi dalam program pembelajaran interprofesional. Responden juga menyatakan sikap positif terhadap perlunya dukungan administrasi kampus dalam upaya pembelajaran interprofesional. WHO mendukung hasil tersebut dimana dukungan intitusi, administrasi kampus, dan logistik merupakan hal penting yang menjadi perhatian dalam pelaksanaan IPE. ${ }^{5}$

\section{KESIMPULAN}

Dari hasil penelitian diatas menujukkan bahwa sebagian besar dosen dari masingmasing program studi yang ada memiliki sikap yang baik terhadap IPE. Sikap dosen tidak berbeda berdasarkan program studi, jenis kelamin, lama mengajar dan pendidikan terakhir. Institusi pendidikan diharapkan dapat mengaplikasikan dan mengembangan proses pembelajaran interprofesional secara terpadu. Penelitian selanjutnya diharapkan dapat dilakukan untuk menganalisa model pembelajaran IPE yang dapat diterapkan secara efektif di lingkup akademik.

\section{TERIMA KASIH}

1. KuswantoHadjo, dr., M.Kes, Ketua Stikes Jenderal Achmad Yani Yogyakarta, email: info@stikesayaniyk.ac.id

2. Muhamat Nofiyanto, M.Kep, Ketua PPPM Stikes Jenderal Achmad Yani Yogyakarta, (0274)4342000, email: pppm@stikesayaniyk.ac.id

\section{KEPUSTAKAAN}

1. CAIPE. Defining IPE. Centre for the Advancement of Interprofessional education, CAIPE 2002, diakses tanggal 5 November 
$<$ http://caipe.org.uk/about-us/definingipe/>

2. American College of Clinical Pharmacy (ACCP). Interprofessional education: Principles and Application, A Framework for Clinical Pharmacy. Pharmacotherapy 2009, 29 (3), 145-164e.

3. Lestari, E. Menumbuhkan Ketrampilan Kepemimpinan dan Team-Building serta Penghargaan terhadap Profesi Lain Melalui Interprofessional Education Analisis Kemungkinan Penerapannya Pada Fakultas Kedokteran di Indonesia. Sains Medika Journal of Medicine and Health 2011: 3(1), http://dx.doi.org/10.30659/sainsmed.v3i1. 86

4. Canadian Interprofessional Health Collaborative (CIHC). (2010). A National Interprofessional Competency Framework, diaksestanggal 8 November 2014,

<http://www.cihc.ca/files/CIHC_IPCompe tencies_Feb1210.pdf>

5. WHO. Framework for Action on Interprofessional education\& Collaborative Practice. Health Professions Networks Nursing \& Midwifery Human Resources for Health, World Health Organization, Department of Human Resources for Health, 2010, $\mathrm{CH}-1211$ Geneva 27, Switzerland.

6. Finch J. Interprofessional education and Team Working: A View From The Education Provider. British Journal of Medicine; 2000, 321:1138-1140.

7. Curran, V.R., Sharpe, D. \& Forristall, J. (2007). Attitudes of Health Sciences
Faculty Members Towards Interprofessional teamwork and education. Blackwell Publishing, Medical Education 2007; 41:892896.doi:10.1111/j.13652923.2007.02823.x

8. Delnat, Catherin C. A Study Of Attitudes Of Faculty And Administrators Towards Interprofessional education. The College of Graduate and Professional Studies and the Department of Advanced Practice Nursing Indiana State University Terre Haute, Indiana, 2012. diakses tanggal 8 November 2014, <http://scholars.indstate.edu/bitstream/10 484/3987/1/Catherine\%20Delnat.pdf>

9. Azwar, S. Sikap Manusia, Teori, dan Pengukurannya. Yogyakarta: Pustaka Pelajar, 2005

10. Barr, H., Koppel, I., Reeves, S., Hammick, M. \&Freeth, D. Effective Interprofessional education: Argument, Assumption and Evidence. 1st ed.Blackwell Publishing. Oxford, 2005.

11. Baker, C., Pulling, C., McGraw, R., Dagnone, J. D., Hopkins-Rosseel, D., \&Medves, J. Simulation in Interprofessional Education for PatientCentred Collaborative Care. Journal of Advanced Nursing 2008: 64(4); 372-379

12. Curran, Vernon. Interprofessional education for Collaborative PatientCentred Practice, Research Synthesis Paper. Canada : Centre for Collaborative Health Professional Education Memorial University, 2004. 